\title{
Cretaceous-Cenozoic regional stress field evolution from borehole imaging in the southern Jinzhou area, western Liaoning, North China Craton
}

\author{
ChengWei Yang1, ChengHu Wang ${ }^{1}$, GuiYun Gao ${ }^{1}$, and Pu Wang ${ }^{2}$ \\ ${ }^{1}$ National Institute of Natural Hazards, Ministry of Emergency Management of China, Beijing 100085, China; \\ ${ }^{2}$ School of Civil Engineering, Tianjin University, Tianjin 300072, China
}

Key Points:

- A four-stage stress field evolution model is proposed.

- Regional stress field, temperature, depth and lithology influenced the occurrence of tensile fractures.

- A counterclockwise trend of the orientation of regional stress field has persisted to present.

Citation: Yang, C. W., Wang, C. H., Gao, G. Y., and Wang, P. (2022). Cretaceous-Cenozoic regional stress field evolution from borehole imaging in the southern Jinzhou area, western Liaoning, North China Craton. Earth Planet. Phys., 6(1), 123-134.

http://doi.org/10.26464/epp2022001

\begin{abstract}
The Mesozoic Yanshanian Movement affected the tectonic evolution of the North China Craton (NCC). It is proposed that Mesozoic cratonic destruction peaked 125 Ma, possibly influenced by subduction of the western Pacific Plate beneath the Euro-Asian Plate in the Early Cretaceous. The southern Jinzhou area in the eastern block of the NCC preserves clues about the tectonic events and related geological resources. Studies of the regional stress field evolution from the Cretaceous to the Cenozoic can enhance our understanding of the tectonics and dynamics of the NCC. Borehole image logging technology was used to identify and collect attitudes of tensile fractures from 11 boreholes; these were subdivided into four groups according to dip direction, i.e., NNW-SSE, NWW-SEE, W-E and NE-SW. The development of these fractures was controlled primarily by the regional tectonic stress field; temperature, lithology, and depth contributed to some extent. In 136-125 Ma in the Early Cretaceous, the area was characterized by extension that was oriented NNW-SSE and NWW-SEE; from 125-101 Ma the extension was oriented W-E; after $101 \mathrm{Ma}$ it was NE-SW. This counterclockwise trend has persisted to the present, probably related to oblique subduction of the Pacific Plate, and is characterized by ongoing extension that is nearly N-S-oriented and NEE-SWW-oriented compression.
\end{abstract}

Keywords: stress field; tensile fracture; borehole; southern Jinzhou; North China Craton

\section{Introduction}

The North China Craton (NCC) experienced a series of large-scale Mesozoic tectonic events termed the "Yanshanian Movement" by Wong WH (1927). These tectonic events were characterized by intra-continental extension and lithospheric thinning, with mantle uplift and a shift in basin-and-range structures from W-E orientation to NNE-SSW (Wang GH et al., 2001; Zhang CH et al., 2001; Zhai MG and Fan QC, 2002; Zhai MG et al., 2004; Shao JA et al., 2006; Liu JL et al., 2008; Zhai MG, 2019) and with a short-term compression in 100-67 Ma that was oriented NWW-SEE (Liu SF et al., 2013, 2017). Studies completed under the Major Research Plan "Destruction of the NCC" have proposed that Mesozoic cratonic destruction peaked ca. $125 \mathrm{Ma}$, possibly influenced by subduction of the western Pacific Plate beneath the Euroasian Plate in the Early Cretaceous (Zhai MG et al., 2004; Shao JA et al., 2006; Li Z et al.,

Correspondence to: C. H. Wang, huchengwang@163.com

Received 17 JUN 2021; Accepted 31 AUG 2021.

Accepted article online 13 JAN 2022.

(C) 2022 by Earth and Planetary Physics.
2007; Zheng TY et al., 2007; Liu JL et al., 2008; Tang QS and Chen L, 2008; Xu YG et al., 2009; Zhang ZJ et al., 2011; Zhu RX et al., 2011, 2012, 2015; Faure et al., 2012; Hou QL et al., 2012). Multi-stages of tectonic stress fields affected the Yanshanian area in the Late Jurassic and Early Cretaceous, based on the fault slide data (Ma Y, 2004; Lin Y et al., 2015; Gao JW et al., 2019). The Jinzhou area in the western Liaoning Province, located in the east of the NCC (Zhao GC et al., 2005; Figure 1), hosts abundant mineral, oil, and gas resources. Mineralization occurred mainly in the Mesozoic (Zhai MG, 2019), while oil- and gas-bearing layers were deposited mainly during the Cenozoic (Li W et al., 2018, 2019; Hu ZW et al., 2019a, b). From the Cenozoic onward, the area has experienced continuous basin formation and uplift due to coeval fault block activity and regional tectonic uplift (Zhang J et al., 2017; He J et al., 2018; Li W et al., 2018, 2019; Hu ZW et al., 2019a, b). However, there are not many detailed studies on the tectonic stress field evolution in the NCC and Western Liaoning area.

As the main driver of tectonic events, the tectonic stress field is related to the evolution of the regional tectonic framework, as well 
as the formation, preservation, and exploration of geological resources. Accurate inversion of paleo-tectonic stress fields is critical to reconstructions of regional geological history. Fractures are generated by crustal brittle deformation and their attitudes have special relationships with the principal stress directions $\left(\sigma_{1}, \sigma_{2}\right.$, and $\sigma_{3}$ ). Because fractures are excellent indicators of paleostress (Engelder and Geiser, 1980; Seeburger and Zoback, 1982; Pollard and Aydin, 1988; Hancock and Engelder, 1989; Morin et al., 1990; Becker and Gross, 1996; Bai TX and Pollard, 2000; Eyal et al., 2001), they have been widely used for paleostress field reconstructions (Engelder and Geiser, 1980; Brereton et al., 1991; Becker and Gross, 1996; Arlegui and Simón, 2001; Jiang L et al., 2016; Fang HH et al., 2017; Shalaby, 2017; Carvalho, 2018).

Developments in deep-Earth detection technology have led to the widespread use of borehole image logging technology in many fields, such as engineering investigations, civil engineering, and mining engineering. In the field of Earth sciences, data from this technology have several useful applications, including accurate characterization of fractures in outcrops and cores (to evaluate rock quality), identification of optimal locations for installation of detectors based on instrument types, and identification of the maximum principal stress direction, etc. (Clerke, 1989; Brereton et al., 1991; Shi YY, 2010; Cui SX and Wang HL, 2011; Fang LP, 2015). Traditional fieldwork in structural geology has been limited to identifying fractures observable in outcrops, which has made structural analysis difficult in areas containing many Quaternary sediments. However, boreholes allow researchers access to rock and fracture information in the deep crust, even in areas influenced by complicated structures, plutons, and fluids (Plumb and Hickman, 1985; Clerke, 1989; MacLeod et al., 1994; Shi YY, 2010; Cui SX and Wang HL, 2011; Fang LP, 2015). Therefore, the use of borehole image logging technology to identify crustal fractures and to analyze structures and stress fields is gradually gaining acceptance; however it has not yet found widespread use (Plumb and Hickman, 1985; MacLeod et al., 1994; Nie X et al., 2013).

In this paper, the southern Jinzhou area in the western Liaoning Province was selected to conduct structural analysis based on fracture information identified via borehole televiewer (Figure 1). The aim of this investigation is to study the evolution of the tectonic stress field in this region, from the Cretaceous to the Cenozoic, in order to provide a base of reference for studies on the formation, preservation, and exploration of geological resources, crustal stress status, and subsequent tectonic evolution and dynamics in this area.

\section{Regional Geological Setting}

\subsection{Sedimentary Sequence}

In the study area's $172.85 \mathrm{~km}^{2}$, the sediments are mainly Cretaceous and Quaternary System (Table 1), of which the Quaternary

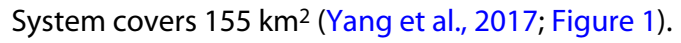

\subsubsection{Yixian formation $\left(K_{1} y\right)$}

The Yixian formation occurs around the Wanjiatun and Gaoqiao in the southwest, with area and thickness of $0.51 \mathrm{~km}^{2}$ and more than $172 \mathrm{~m}$, respectively. From bottom to top, the Formation is dominated by rhyolitic volcanic breccias, dacitic volcanic breccias, volcanic agglomerates, rhyolites, rhyolitic volcanic breccias, conglomerates, and rhyolites.

\subsubsection{Sunjiawan formation $(K, s)$}

The Sunjiawan formation occurs around the Qiaoniao-Dong-
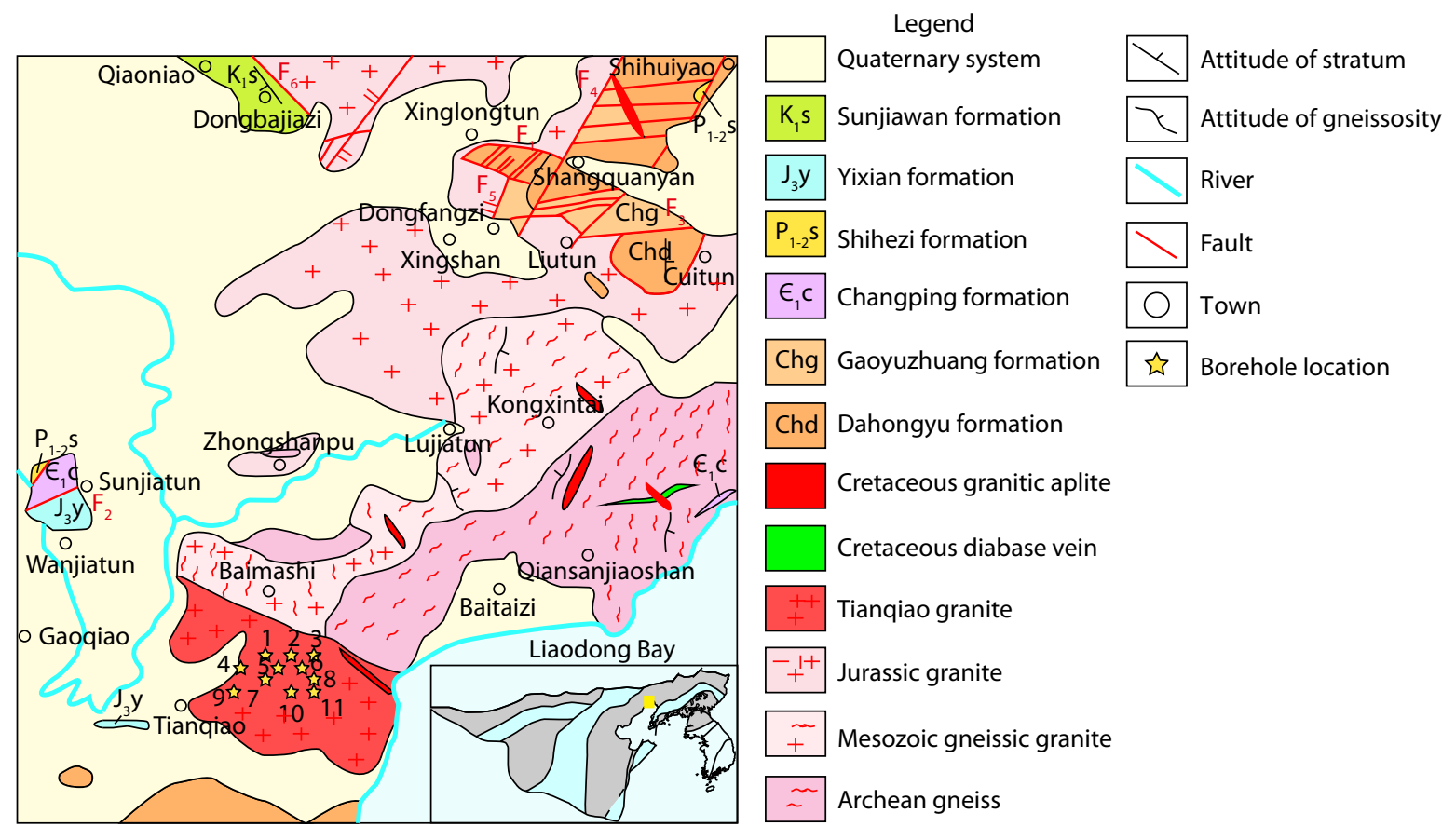

Figure 1. Regional geological map of the southern Jinzhou area (1-ZK22, 2-ZK30, 3-ZK38, 4-ZK17, 5-ZK27, 6-ZK35, 7-ZK24, 8-ZK40, 9-ZK21, 10$Z K 33,11-Z K 41$, $F_{1}$-Xinglongtun-Shangquanyan fault, $F_{2}$-western Sunjiatun fault, $F_{3}$-Liutun-Cuitun fault, $F_{4}$-Dongfangzi-Shihuiyao fault, $F_{5}-$ Xingshan fault, $\mathrm{F}_{6}$-Qiaoniao-Dongbajiazi fault). 
Table 1. Regional strata in the southern Jinzhou area.

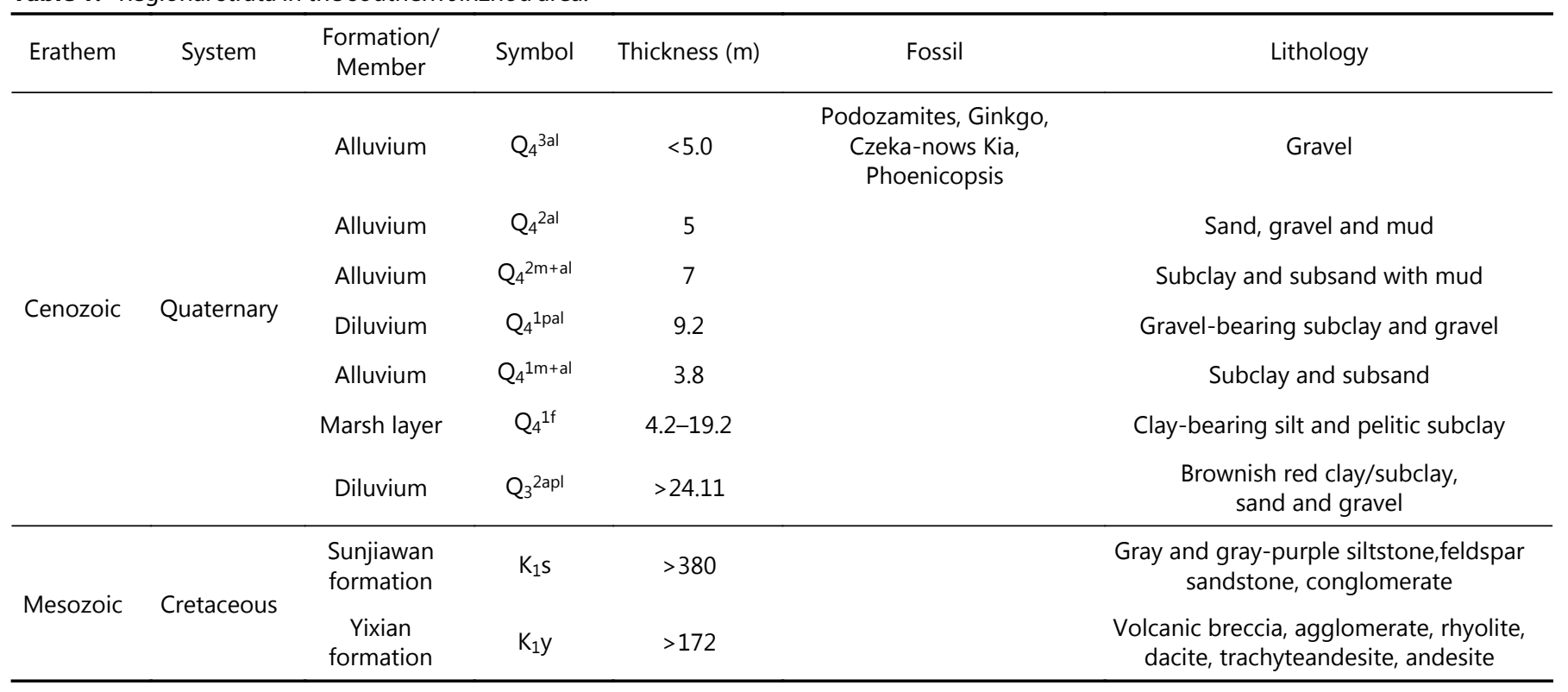

bajiazi in the northwest, with area and thickness of $1.78 \mathrm{~km}^{2}$ and more than $380 \mathrm{~m}$, respectively, and has contact, separated by a fault, with the Kongxintai gneissic complex. This formation consists mainly of conglomerates with complicated compositions, of which the gravels are andesites, granites, and quartz sandstones.

\subsubsection{Quaternary System (Q)}

The Quaternary System contains Pleistocene Series diluvial deposits $\left(Q_{3}\right)$ and Holocene Series alluvial deposits $\left(Q_{4}\right)$. The Pleistocene Series diluvial deposits are found along the edges of hilly platforms, with thicknesses varying from $5 \mathrm{~m}$ to more than $24.11 \mathrm{~m}$. The uppermost sediments are characterized by yellowish-brown and brownish-red clays or subclays while the lower parts are dominated by sands and gravels.

The Holocene Series, comprising $90 \%$ of the Quaternary System, is widespread in this area with various compositions, i.e., marshes, diluviums, and alluviums, of which the alluvial deposits are the most developed.

\subsection{Mesozoic Tectonics}

The study region, located in the eastern part of the Yanshanian orogenic belt in the NCC, has undergone two stages of major tectonic events. First, during the Early-Middle Jurassic to the Early Cretaceous, it experienced compression related to closure of the Mongol-Okhotsk Ocean and subduction of the Pacific Plate; later, following the Early Cretaceous, it experienced extension related to subduction of the Pacific Plate, peaking at 125 Ma (Zhao Y, 1990; Zhao Y et al., 1994, 2002; Wang Y, 1996; Shao J et al., 2000, 2006; Zheng YD et al., 2000; Zhai MG and Fan QC, 2002; Zhai MG et al., 2004; Li Z et al., 2007; Yang W, 2007; Zheng TY et al., 2007; Liu JL et al., 2008; Tang QS and Chen L, 2008; Xu YG et al., 2009; Zhang ZJ et al., 2011; Zhu RX et al., 2011, 2012, 2015; Faure et al., 2012; Hou QL et al., 2012; Liu SF et al., 2013, 2021; Yang Z et al., 2017; Zhai MG, 2019). In particular, tectonic analysis and "deep-time" reconstruction of the western Pacific subduction and deformation in northeast Asia since $200 \mathrm{Ma}$ indicates a NW-SE-oriented shortening from 200-137 Ma, a NWW-SEE-oriented extension from 136-101 Ma, then from 100-67 Ma a nearly N-S-oriented extension and uplift with a short-term NWW-SEE-oriented compressional inversion in northeast China, , and from $66 \mathrm{Ma}$ to the present day a NW-SE- and nearly N-S-oriented extension (Liu SF et al., 2017).

Major faults in this area are related to three stages of deformation, defined according to their timing and strike (Yang W, 2007; Yang $Z$ et al., 2017; Figure 1). The first stage of deformation generated W-E-striking thrust faults, including the Xinglongtun-Shangquanyan, western Sunjiatun, and Liutun-Cuitun faults, resulting in Jurassic layers becoming covered by older layers during the MiddleLate Jurassic N-S-oriented compression related to closure of the Mongol-Okhotsk Ocean and subduction of the Pacific Plate. The second stage of deformation is characterized by NE-SW-striking normal and strike-slip faults, e.g., the Dongfangzi-Shihuiyao and Xingshan faults, caused in the Early-Middle Cretaceous by NW-SEoriented extension, along with NE-SW-striking strike-slip due to subduction of the Pacific Plate. The third stage of deformation, in the Middle-Late Cretaceous and Cenozoic, related to Pacific Plate subduction, is characterized by some NW-SE-striking normal and strike-slip faults, e.g., the Qiaoniao-Dongbajiazi fault, generated by NE-SW-oriented extension and NW-SE-oriented strike-slip. The deposition and distribution of Cretaceous sedimentary layers were influenced by both the second and the third stages of deformation. Extension and strike-slip activity in the region continued until the Cenozoic (Zhao Y, 1990; Zhao Y et al., 1994, 2002; Wang Y, 1996; Liu JZ et al., 2000; Zheng YD et al., 2000; Liu JL et al., 2008; Liu JY et al., 2018; Zhai MG et al., 2004; Shao JA et al., 2000, 2006; Li Z et al., 2007; Yang W, 2007; Zheng TY et al., 2007; Tang QS and Chen L, 2008; Yang W and Li SG, 2008; Xu YG et al., 2009; Zhang ZJ et al., 2011; Zhang J et al., 2017; Zhu RX et al., 2011, 2012, 2015; Faure et al., 2012; Hou QL et al., 2012; Li W et al., 2018, 2019; Xu XC et al., 2017; He J et al., 2018; Hu ZW et al., 2019a, b; Zhai MG, 2019). 


\subsection{Mesozoic Magmatic Rocks}

The main Mesozoic magmatic rocks in the study area are the Tianqiao granites, which are oval-shaped and extend for an area of $7.6 \mathrm{~km}^{2}$ into the Bohai sea (Figure 1). Intruding into them are later diabases, diorite porphyrite, and granitic aplite veins.

Biotite K-Ar dating by the Liaoning Bureau of Geology and Mineral exploration demonstrated that the Tianqiao granites were emplaced at $107.5 \pm 2.4 \mathrm{Ma}$, indicating that they are related to magmatic events in the Early Cretaceous. Petrogenetic and geochemical characteristics indicate that they are S-type granites derived from crustal thinning and mantle uplift in an extensional setting (Liu JZ et al., 2000; Xu XC et al., 2017).

The Tianqiao granites are light red with a moderately coarsegrained texture and a massive structure. The dominant minerals are K-feldspars and quartzs with minor amphiboles and biotite. They are strongly weathered on the surface with a thickness of over $15 \mathrm{~m}$, and are easily smashed. The original magmatic fabrics cannot be observed in the weathered surface outcrops, but are evident in samples from the deeper crust below the surface.

The diabase veins intruding into the Tianqiao granites range from light to dark gray in color and have diabasic texture and a massive structure, with a mineralogy of mainly pyroxenes and plagioclases with minor amphiboles and biotites. The diorite porphyrite veins occur in bands within the Tianqiao granites and are light gray-brown in color with banded, porphyritic textures and a massive structure. The phenocrysts consist of amphiboles; the stromas are amphiboles and plagioclases. Similarly, the granitic aplite veins also occur as bands in the Tianqiao granites, are red in color, and have aplitic texture and a massive structure with minerals consisting mainly of plagioclases, K-feldspars, and quartzs with few dark minerals.

\section{Methodology}

The data and images in this paper were obtained by the borehole televiewer from boreholes in the southern Jinzhou area, located $35 \mathrm{~km}$ from the downtown (Figure 1). The existing stress tensors equal the sum of the distant, regional, and local stress tensors from different sources (Jiang $L$ et al., 2016). The chosen area is far from major faults in the Jinzhou area, so that the attitudes of fractures in this area are mainly controlled by distant and regional stresses. The data and images were collected from 11 boreholes whose identifiers are ZK17, ZK21, ZK22, ZK24, ZK27, ZK30, ZK33, ZK35, ZK38, ZK40, and ZK41. Data processing was conducted using the software WellCAD, which is capable of processing and interpreting live data. Patterns, depths, dip directions and dips of fractures are presented directly (Figure 2). Then the tensile fractures can be identified and their dip directions can be obtained.

Tensile fractures are the result of brittle deformation. They correspond to Mode I fractures that propagate normal to the minimum principal stress $\sigma_{3}$, in the plane containing $\sigma_{1}$ and $\sigma_{2}$, as a result of true tension $\left(\sigma_{3}<0\right)$, or, at deep levels in the Earth's crust, when tensile effective stress conditions are reached (Figure 3; Pollar and Aydin, 1988; Hancock and Engelder, 1989; Price and Cosgrove, 1990; Brereton et al., 1991; Eyal et al., 2001; Bai TX et al., 2002; Jiang $L$ et al., 2016; Carvalho, 2018). The azimuths of tensile frac- tures therefore represent the horizontal direction of the regional tensile stresses, according to which the regional tectonic stress field evolution can be inferred. Furthermore, tensile fractures with opposite azimuths are treated as one group because they can be generated in an identical extensional tectonic event.

\section{Borehole Data Interpretation}

One hundred and ninety-three tensile fractures were identified by the borehole televiewer and interpreted by the software WELLCAD from the 11 boreholes (Table 2). The details of every tensile fracture can be found at our online dataset; see Data availability, below.

All the azimuths of tensile fractures were counted to plot rose diagrams and Wulff net projections (Figure 4). The rose diagrams indicate the presence of three preferential fracture dip directions, i.e., NWW, SWW, and SSE. The Wulff net projection displays the orientations of lines normal to the tensile fracture planes rather than the planes themselves in a lower hemisphere projection so that the fracture azimuths are presented as points. Three groups of orientations occur with greater frequency in these projections, indicating directions of NNW, NEE, and SEE. Cluster analysis performed on these points highlighted three cluster centers, i.e., $95.69^{\circ} \angle 53.34^{\circ}(n=97), 335.50^{\circ} \angle 4.03^{\circ}(n=43)$, and $306.30^{\circ} \angle 76.56^{\circ}$ $(n=53)$, which represent fractures with attitudes of $275.69^{\circ}$ $\angle 26.66^{\circ}, 155.50^{\circ} \angle 85.97^{\circ}$, and $126.30^{\circ} \angle 13.44^{\circ}$, respectively.

\section{Discussion}

Conventionally, a single tectonic event or a united tectonic stress field is assumed to generate tensile fractures with identical or nearly identical directions. However, the fractures investigated in this paper commonly exhibit two or three distinct directions. Furthermore, the fractures are present in diverse rock types that vary in age, indicating that the fractures may have resulted from multiple stages of tectonic events. Thus, the studied fractures should be further analyzed in the context of their time period of formation.

\subsection{Geochronological Frameworks of Intrusions}

As the tensile fractures studied here occur in magmatic rocks of various types, it is important to understand the timing of magmatic activity to constrain the ages of the fracturing. As mentioned above, biotite K-Ar dating by the Liaoning Bureau of Geology and Mineral exploration is the basis for concluding that the Tianqiao granites were emplaced at $107.5 \pm 2.4 \mathrm{Ma}$, indicating that they are related to Early Cretaceous magmatic events. No subsequent studies of the Tianquo granites have been reported. However, detailed studies have been conducted on the geochronology of volcanic rocks in the western Liaoning Province (Yang W and Li SG, 2008; Xu XC et al., 2017), from which Wu FY et al. (2006) have concluded that the geochronological frameworks of intrusions and extrusions in the western Liaoning Province are incompatible with data from volcanic rocks, which thus cannot be used to constrain the geochronology of the intrusions. In the western Liaoning area, granites become younger toward the west (Wu F et al., 2006). Yangjiazhangzi, Shishan, and Haitangshan plutons of 189-182, 123, and 176-152 Ma are adjacent to the Tianqiao pluton (Wu FY 


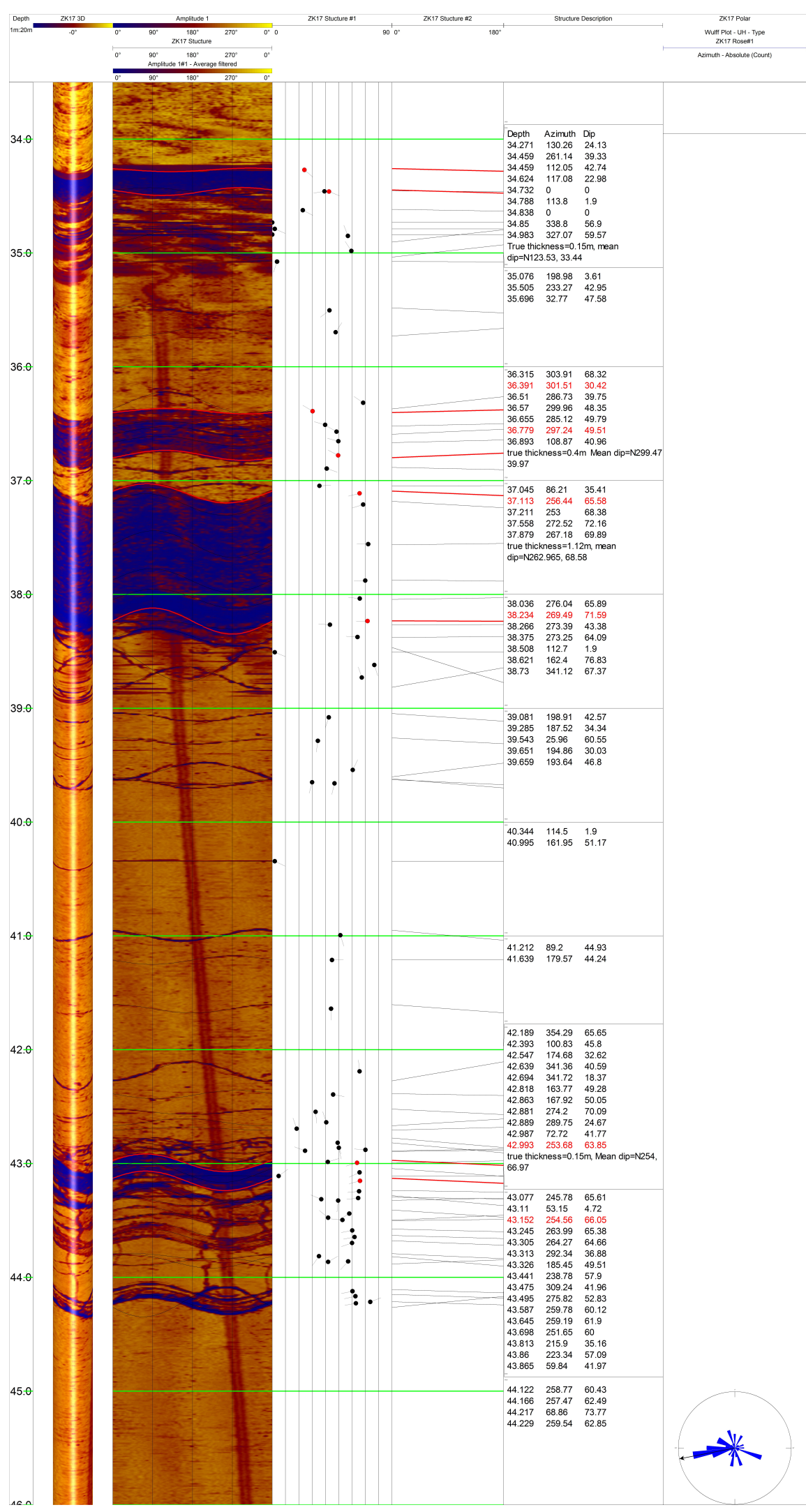

Figure 2. Typical borehole images of the borehole ZK17.

et al., 2006). The Shishan granites are light red with a moderately coarse-grained texture and a massive structure. The dominant minerals are K-feldspars and quartzs with minor amphiboles and biotites, which pattern is identical to the Tianqiao granites. In addition, the Tianqiao granites intrude into the Archean gneisses. The above characteristics are consistent with Cretaceous plutons 
Table 2. Distribution of tensile fractures from each of the eleven boreholes, in terms of count, depth, and lithology.

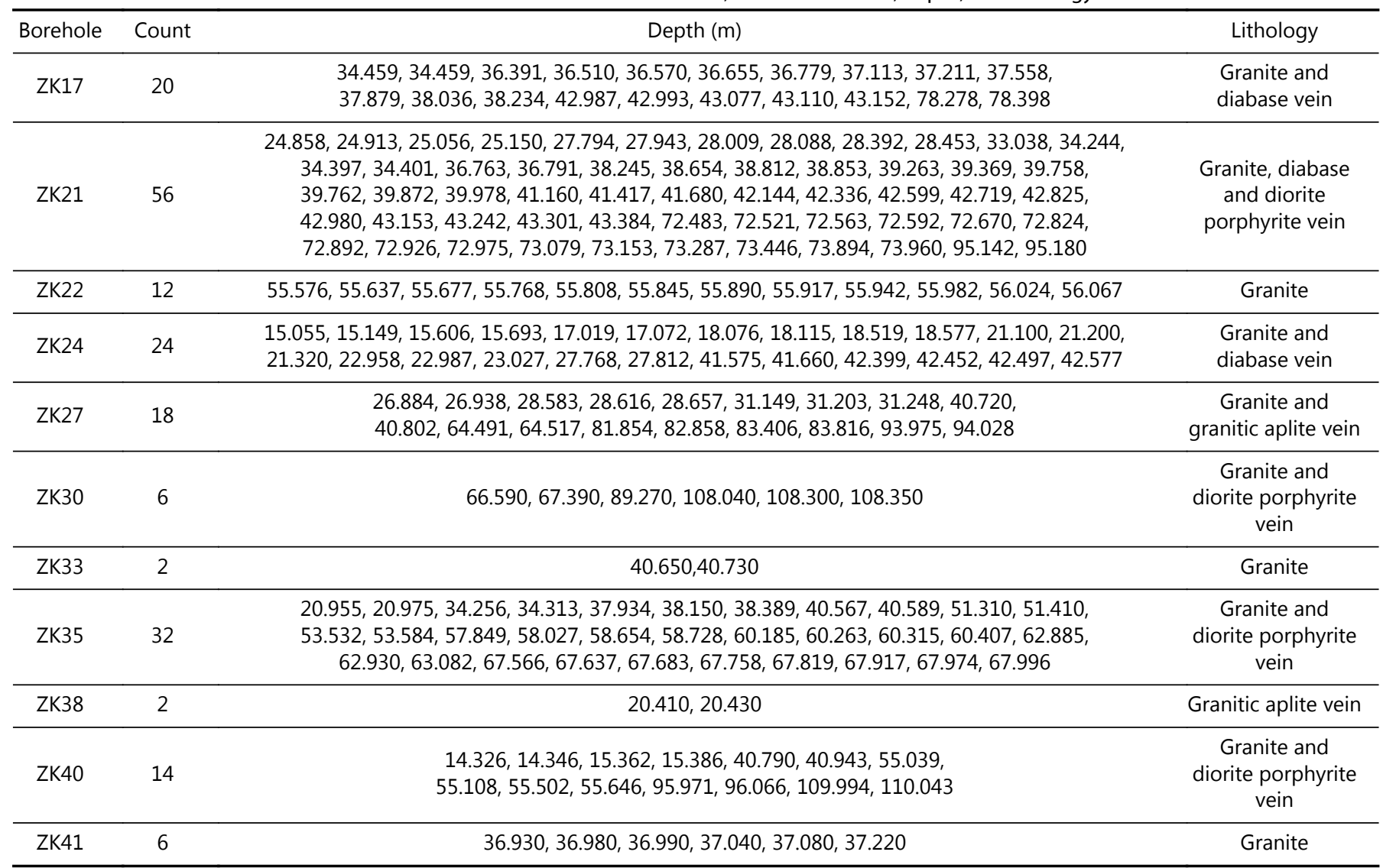

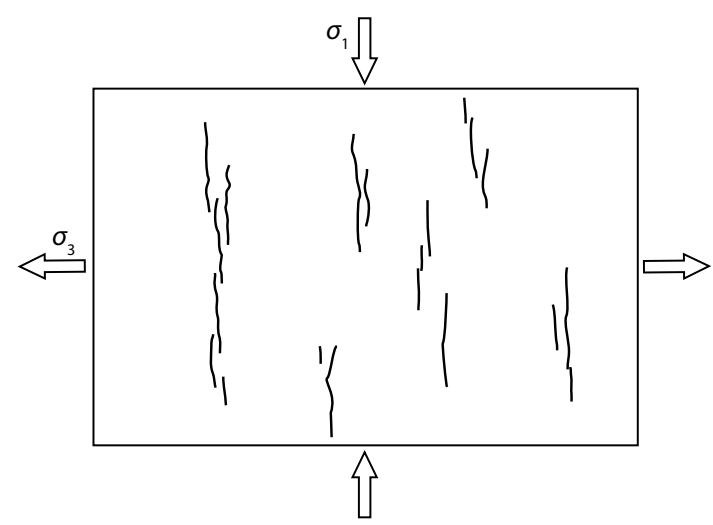

Figure 3. Relationships between attitudes of tensile fractures and directions of stress axes in the extensional setting.

(Jiang SE et al., 2010). Therefore, the Tianqiao granites were likely emplaced in the Early Cretaceous. Notably the intermediate-basic and fine-grained granitic veins in the Haitangshan pluton, northeast of the Jinzhou area, are similar to those in the Tianqiao granites. LA-ICP-MS zircon U-Pb dating indicates that the intermediate-basic veins were emplaced at $125 \mathrm{Ma}$. Additionally, magma mixing occurred among the basic and granitic veins, which suggests that they were generated simultaneously (Wu FY et al., 2006). Therefore, the diabase, diorite porphyrite, and granitic aplite veins were likely emplaced at $\sim 125 \mathrm{Ma}$ in the Early Cretaceous.

Zircon $\mathrm{U}-\mathrm{Pb}$ ages represent the time at which the temperature of the $\mathrm{U}-\mathrm{Pb}$ isotopic system cooled through the closure temperature $\left(\sim 900^{\circ} \mathrm{C}\right)$. At $900^{\circ} \mathrm{C}$, basic magmas have solidified to a state that is susceptible to brittle deformation while acid magmas may still be molten. Additionally, when basic and acid magmas come into contact, the relatively high temperature difference between the two magma types can result in a loss of heat from the basic magma to the acid magma, increasing its cooling and solidification rate. Simultaneously, the heat absorbed by the acid magma causes it to solidify more slowly. Furthermore, diabase veins can be seen to crosscut granitic aplite veins on the geological map (Figure 1). Thus, we suggest that the magmatic veins follow a sequence of diabase, diorite porphyrite, and granitic aplite, from oldest to youngest.

\subsection{Periodization of Tensile Fractures}

When tensile fracture counts are compiled according to rock type, three groups of preferred fracture dip directions are evident in the Tianqiao granites: NNW-SSE, NWW-SEE, and near W-E. Two groups of preferred dip directions, NWW-SEE and W-E, are evident in the diabase; the group with dip direction of NWW-SEE appears in the diorite porphyrite, the group with dip direction of NE-SW occurs in the granitic aplite veins (Figure 5).

Conventionally, time sequence can be identified if there are multiple groups of foliation in a pluton with veins (Figure 6). The $S_{1}$ foliation is developed only in the pluton, indicating that it was generated earlier than the vein but later than the pluton. The $S_{2}$ foliation is developed in both the pluton and the vein, revealing that it was generated later than the pluton and vein. Therefore, the $S_{2}$ 

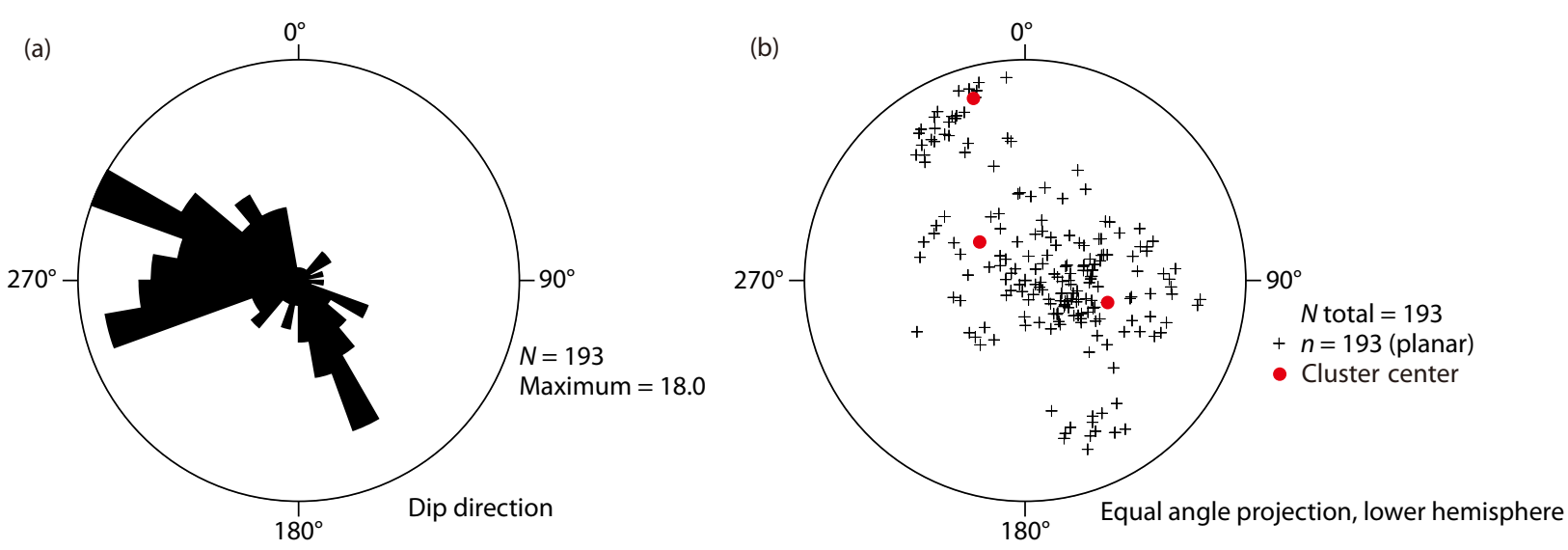

Figure 4. Rose diagram and lower hemisphere projection of all the tensile fractures.
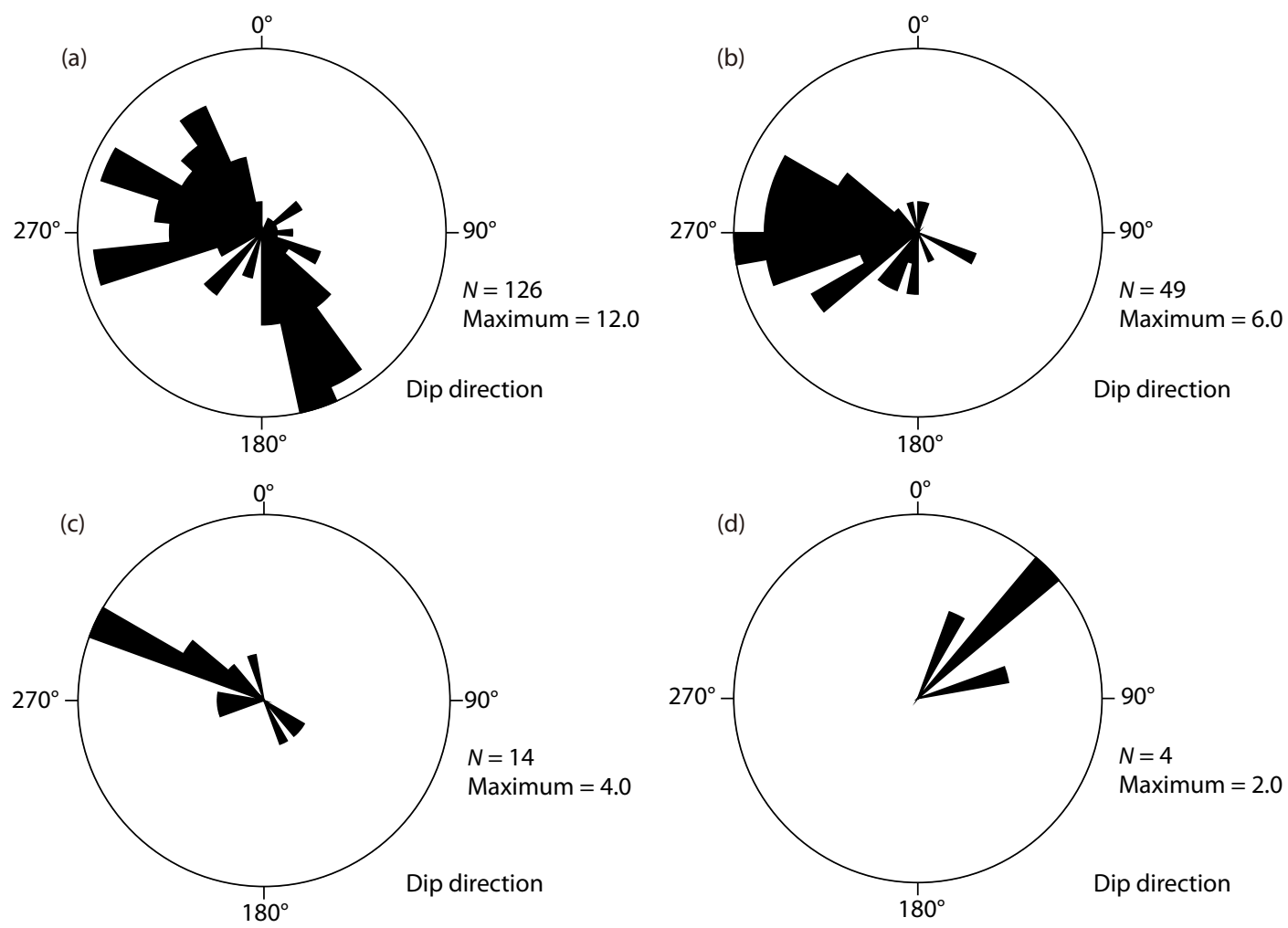

Figure 5. Rose diagrams of tensile fractures in different types of rock. (a) Tianqian Granite; (b) Diabase vein; (c) Diorite porphyrite vein; (d) Granitic aplite vein.

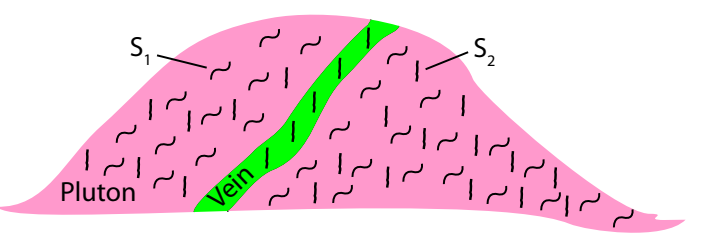

Figure 6. Concept diagram for time sequence of foliations in a pluton with veins.

foliation is younger than the $S_{1}$ foliation.

NNW-SSE-dipping tensile fractures occur only in the Tianqiao granites and are absent in the other three rock types (Figure 5a), suggesting that the NNW-SSE-dipping tensile fractures are the earliest to have formed. The NWW-SEE-dipping tensile fractures are present in all rock types except for granitic aplite veins (Figure $5 a, b, c)$, indicating they are younger than the diabase and diorite porphyrite veins but older than the granitic aplite veins. Therefore, they are younger than the NNW-SSE-dipping tensile fractures. The W-E- and NE-SW-dipping tensile fractures are interpreted to have formed relatively late and to be younger than the granitic aplite veins because W-E-dipping tensile fractures are present in all rock types (Figure 5), as are NE-SW-dipping tensile fractures (Figure $5 a, b, d$ ) with the exception of diorite porphyrite veins. However, it is difficult to define their order of formation solely according to their presence in various magmatic rocks. Not- 
ably, two groups of tensile fracture intersect in the Tianqiao granites. In borehole ZK17 (Figure 2), two sets of tensile fractures with attitudes of $53.15^{\circ} \angle 3.59^{\circ}$ (NE) and $254.56^{\circ} \angle 59.69^{\circ}$ (near W) occur at depths of 43.11 and $43.152 \mathrm{~m}$, respectively. The W-dipping fractures appear clearly to have been transformed and crosscut by the NE-dipping fractures in borehole images, indicating that the W-E-dipping fractures are older than NE-SW-dipping fractures. Additionally, SEE- and W-dipping fractures intersect one another in the diabase veins. In borehole ZK17, two sets of tensile fractures with attitudes of $261^{\circ} \angle 31.91^{\circ}(\mathrm{W})$ and $112.05^{\circ} \angle 35.08^{\circ}$ (SEE) occur at a depth of $34.459 \mathrm{~m}$ (Figure 2). The SEE-dipping fractures clearly appear to have been transformed and crosscut by the Wdipping fracture in borehole images. Similarly, in borehole ZK17 are two sets of tensile fractures with attitudes of $293.34^{\circ} \angle 65.11^{\circ}$ (NWW) and $257.38^{\circ} \angle 53.12^{\circ}(\mathrm{W})$ at depths of 41.074 and $41.160 \mathrm{~m}$, respectively (Figure 2). The NWW-dipping fractures appear to have been transformed and crosscut by the W-dipping fractures in borehole images. The two lines of evidence above demonstrate that the NWW-SEE-dipping tensile fractures are older than those dipping to $\mathrm{W}$ or E. From this, it can be concluded that the order of fracture formation, from earliest to latest, are those with NNW-SSE, NWW-SEE, W-E, and NE-SW dip directions.

\subsection{Factors Affecting the Development of Tensile Fractures}

The development of tensile fractures in rocks is controlled not only by the regional tectonic stress field but also by lithology, temperature, and depth. Diorite porphyrite, granite, and granitic aplite have similar mineral and geochemical compositions and have massive structures. In an identical geological setting, they have similar tensile strengths, which are significantly lower than that of diabase (Caristan, 1982; Stone et al., 1989; Juhlin and Stephens, 2006; Abdelmalak et al., 2012).

NNW-SSE-dipping tensile fractures are present only in the Tianqiao granites because the stress field that produced them was active later than the emplacement of the Tianqiao granites and earlier than the emplacement of veins, which suggests that the development of this group of tensile fracture was controlled by the regional tectonic stress field.

Similarly, the reason that NWW-SEE-dipping tensile fractures oc- cur in all rock types except for granitic aplite veins is that the stress field related to the formation of these fractures was active later than the emplacement of the Tianqiao granites and the diabase and diorite porphyrite veins, and earlier than the emplacement of granitic aplite veins. Therefore, the development of this group of tensile fractures was also controlled by the regional tectonic stress field.

W-E-dipping tensile fractures are present in all rocks types; however, they are the most common fracture orientation in the Tianqiao granites and diabase veins, while being relatively rare in other rock types. The tensile strength of diabase is notably higher than any of the other three rock types, indicating that brittle tensile deformation can occur more easily in the other rock types than in the diabase.

In the Early Cretaceous, W-E-dipping tensile fractures formed later than the granitic aplite veins. Emplacement of the granitic veins was associated with a significant amount of heat. Melting points and the brittle-ductile deformation transition temperature of diabase are sufficiently high that the diabase veins were not affected by the additional heat and continued to deform by brittle mechanisms. Although the melting point and brittle-ductile deformation transition temperature in granite are not as high as those of the diabase, the Tianqiao granites comprise a large rock body. Thus, the Tianqiao granites underwent a relatively small increase in temperature due to heating, and consequently developed abundant W-E brittle tensile fractures. However, the diorite porphyrite veins underwent heating and were near the brittleto-ductile transition while the granitic aplite veins had not yet solidified, resulting in few brittle W-E tensile fractures in these lithologies. It is concluded that this group of tensile fractures resulted from the regional tectonic stress field, temperature, and lithology.

NE-SW-dipping tensile fractures are present in all rock types except for diorite porphyrite veins. It is notable that nearly all NESW-dipping tensile fractures occur at a depth of 0-60 m, while most diorite porphyrite veins exist at depths of greater than $60 \mathrm{~m}$ (Figure 7). The absence of NE-SW-dipping tensile fractures in the diorite porphyrite veins indicates a late stage of deformation related to NE-SW-dipping tensile fractures that only partially influenced rocks in relatively shallow crust. It is concluded that this

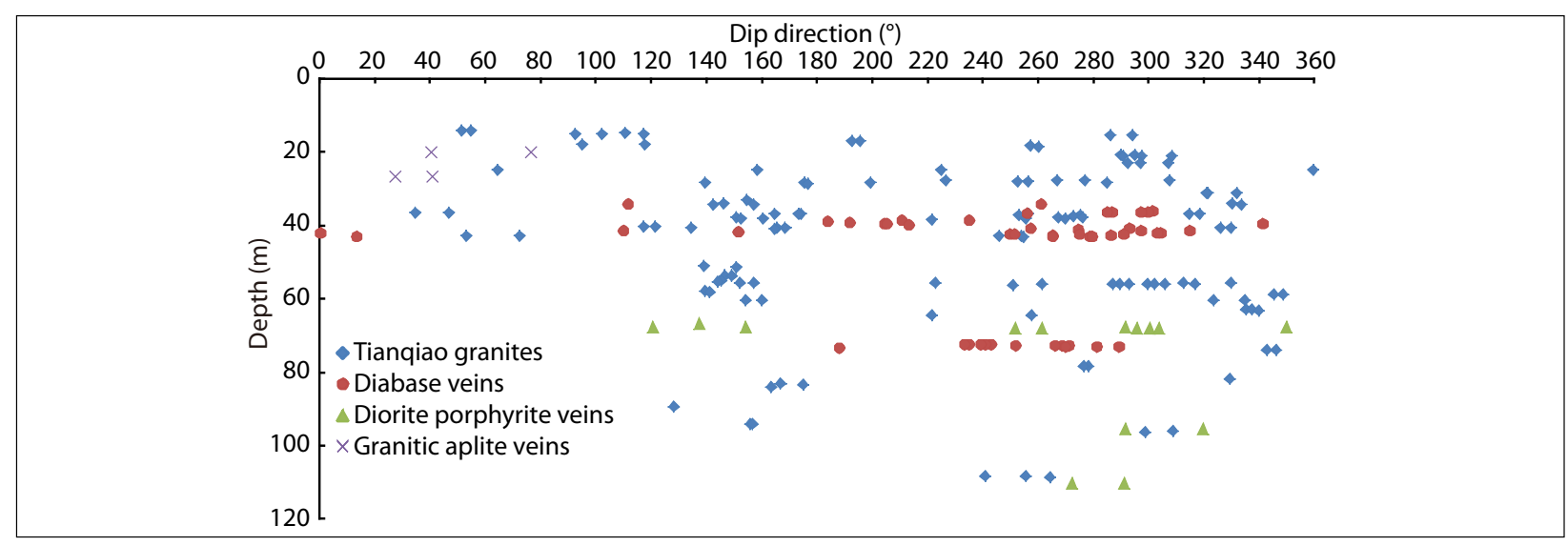

Figure 7. Relationships between tensile fractures and depths. 
group of tensile fracture is controlled primarily by regional tectonic stress field and depth.

In conclusion, we suggest that the development of all the tensile fractures can be attributed to the influence of regional tectonic stress fields.

\subsection{Regional Tectonic Stress Field Evolution}

Previous studies of the tectonics, magmatic activity, and sedimentary records show that the western Liaoning Province was mainly in the extension and extension-strike-slip settings during the Cretaceous and Cenozoic with a short-term compression (Zhao Y, 1990; Zhao Y et al., 1994, 2002; Wang Y, 1996; Shao JA et al., 2000, 2006; Zheng YD et al., 2000; Zhai MG and Fan QC, 2002;
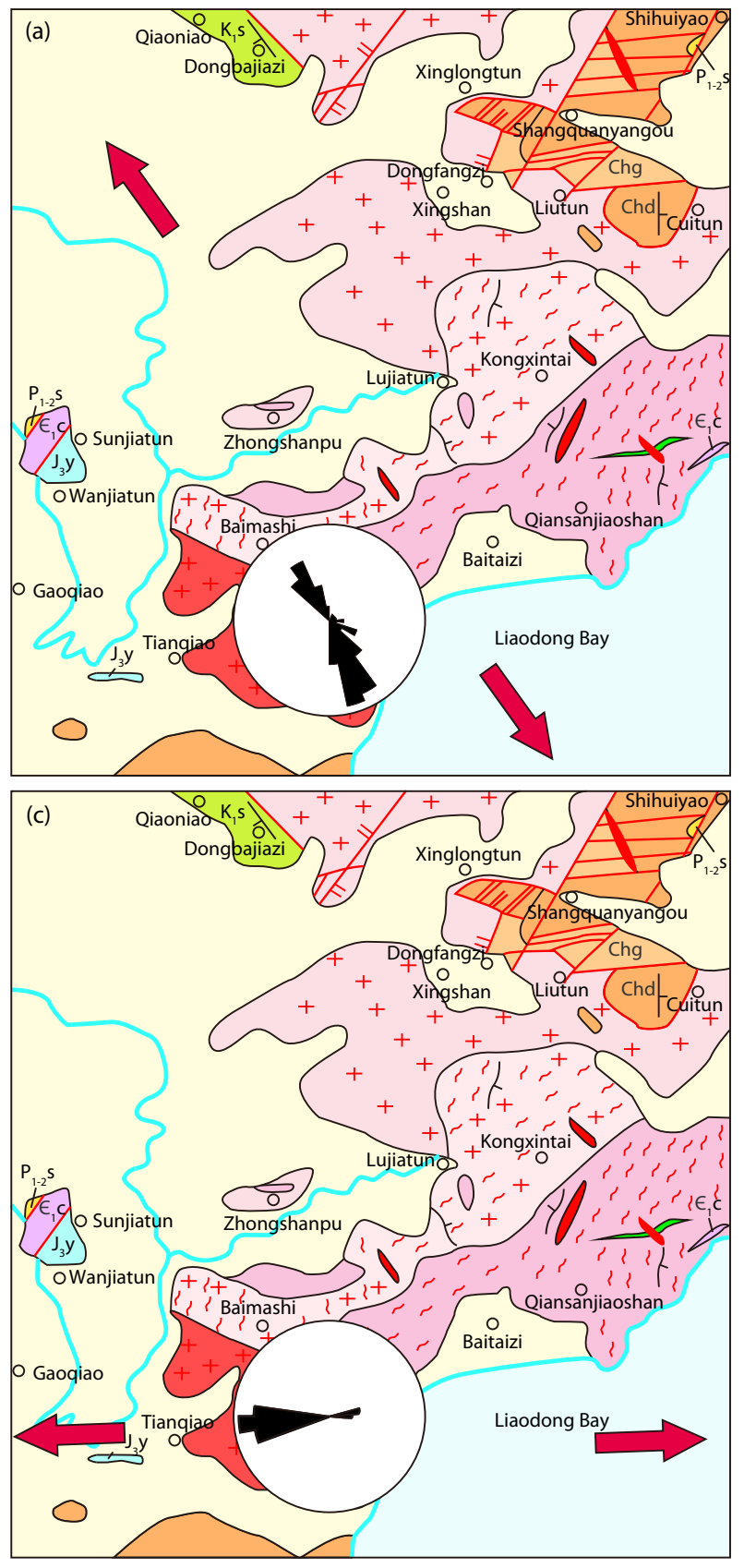

Zhai MG et al., 2004; Li Z et al., 2007; Yang W, 2007; Zheng TY et al., 2007; Liu JL et al., 2008; Tang QS and Chen L, 2008; Xu YG et al., 2009; Zhang ZJ et al., 2011; Zhu RX et al., 2011, 2012, 2015; Faure et al., 2012; Hou QL et al., 2012; Liu SF et al., 2013, 2017, 2021; Yang $Z$ et al., 2017; Zhai MG, 2019). From the Cretaceous to present, the northeast of Asia has undergone a NWW-SEE-oriented extension from 136-101 Ma, a nearly N-S-oriented extension and uplift with a short-term NWW-SEE-oriented compressional inversion in northeast China from 100-67 Ma, and a NW-SE- and nearly N-S-oriented extension from $66 \mathrm{Ma}$ to the present day (Liu SF et al., 2017).

Our findings indicate that the regional tectonic stress field evolution in the southern Jinzhou area was driven by subduction of the
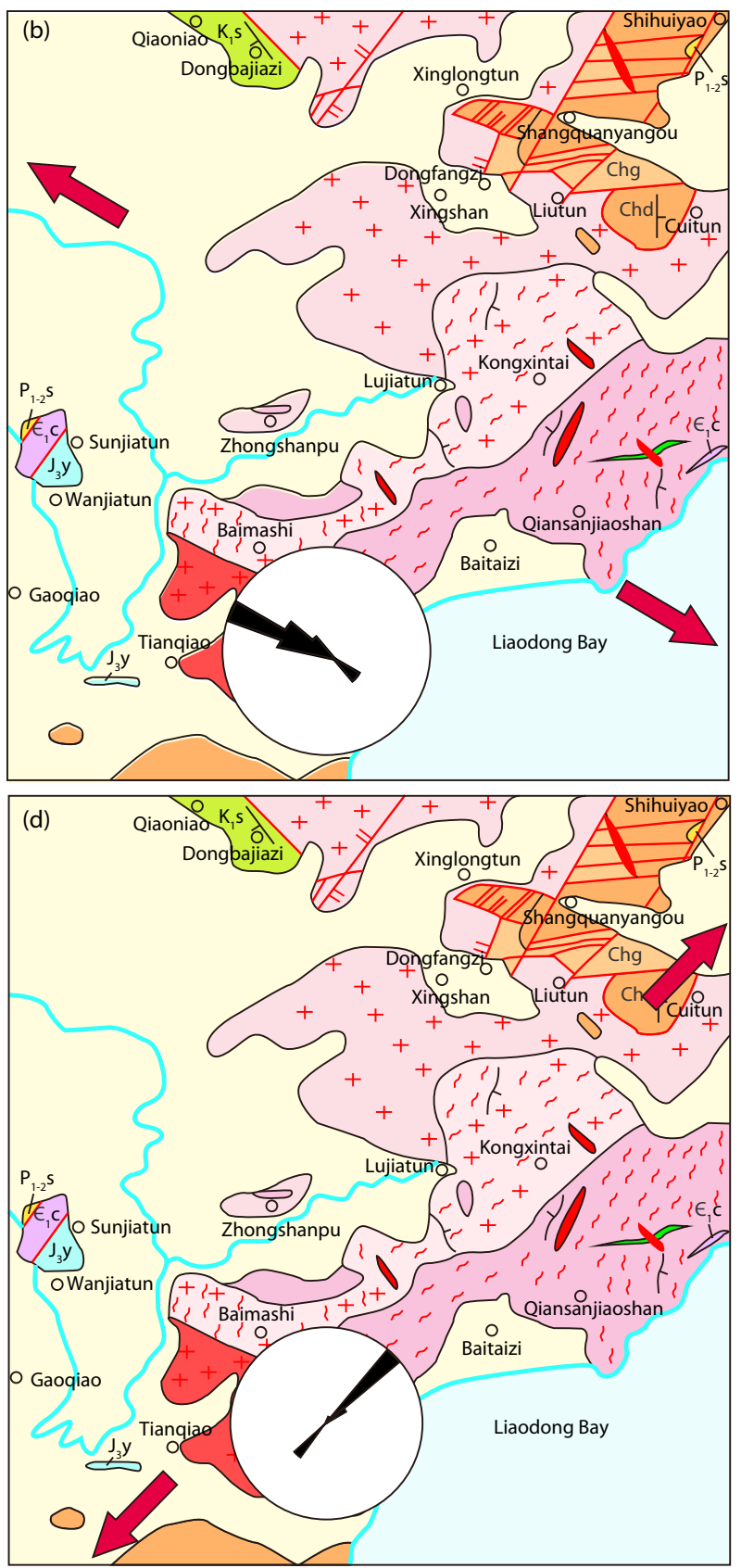

Figure 8. Regional tectonic stress field evolution from the Cretaceous to Cenozoic. 

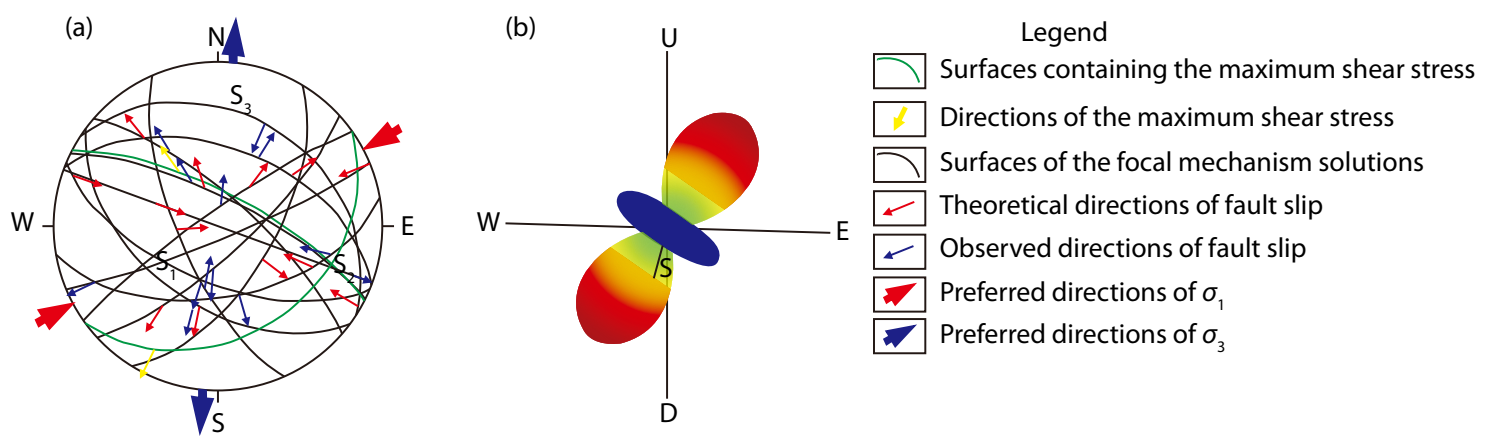

Figure 9. Present tectonic stress field state in western Liaoning Province. (a) The results based on focal mechanism solutions; (b) The 3-D stress status; U-up, D-down; revised after Dai YL et al. (2020).

Pacific Plate and can be subdivided into four stages (Figure 8).

The first stage (136-125 Ma) is characterized by the formation of tensile fractures dipping NNW-SSE solely in the Tiaoqiao granites, driven by regional NNW-SSE-oriented extension. The second stage (ca. $125 \mathrm{Ma}$ ) is characterized by the formation of tensile fractures dipping to NWW and SEE in the Tianqiao granites, diabase, and diorite porphyrite veins, driven by regional NWW-SEE-oriented extension at $125 \mathrm{Ma}$. The above two stages of deformation were responsible for regional NE-SW-striking normal faults. The third stage (125-101 Ma) is characterized by the formation of tensile fractures dipping to nearly $\mathrm{W}$ or $\mathrm{E}$ in the Tianqiao granites, diabase, diorite porphyrite, and granitic aplite veins and was driven by regional W-E-oriented extension, though there are few faults or folds related to this deformation stage. The final stage (after $101 \mathrm{Ma}$ ) has been characterized by the formation of tensile fractures dipping to NE and SW in the Tianqiao granites, diabase, and granitic aplite veins, driven by regional NE-SW-oriented extension, which is responsible for the formation of regional NW-SEstriking normal faults.

Additionally, Dai YL et al. (2020) have suggested, based on earthquake focal mechanism solutions from Liaoning Province (Figure 9), that the western Liaoning Province is presently in an extensional setting, with nearly N-S-oriented extension and NEESWW-oriented compression; this characterization is consistent with the world stress map (Zoback, 1992) and the crustal stress pattern in China (Hu XP et al., 2017). Therefore, the regional tectonic stress field in the southern Jinzhou area has undergone a counterclockwise evolution since the Early Cretaceous to the present that may be related to rotation of the subduction direction of the Pacific Ocean Plate.

\section{Conclusions}

(1) This study, based on borehole image logging technology, demonstrates that tensile fractures occur widely throughout Cretaceous magmatic rocks in the southern Jinzhou area. These fractures can be subdivided into four groups according to azimuth and rock type, i.e., NNW-SSE-dipping tensile fractures present only in the Tianqiao granites, NWW-SEE-dipping fractures that occur in all rock types except for granitic aplite veins, W-Edipping fractures that occur in all rock types, and NE-SW-dipping fractures present in all rock types except for diorite porphyrite veins. We conclude that formation of all the tensile fractures was controlled primarily by the regional tectonic stress field.

(2) The southern Jinzhou area was mainly in an extensional setting that has undergone regional tectonic stress field evolution, with successive stages of NNW-SSE-, NWW-SEE-, W-E-, and NE-SWoriented extension in 136-125 Ma, ca. $125 \mathrm{Ma}, 125-101 \mathrm{Ma}$ and after $101 \mathrm{Ma}$, respectively, from the Cretaceous to the Cenozoic.

(3) The counterclockwise trend of direction of extensional stress has persisted to the present time, which is characterized by ongoing nearly $\mathrm{N}$-S-oriented extension and NEE-SWW-oriented compression in this area.

\section{Acknowledgments}

This study is supported by the National Natural Science Foundation of China (41574088). Assistance from Mr. Hao Zhou, Xueyong Wei, Nian Chen and Hong Wang is appreciated.

\section{Data availability}

Datasets related to this article can be found at https://data. mendeley.com/datasets/bby6h3zfsm/1, an open-source online data repository hosted at Mendeley Data.

\section{References}

Abdelmalak, M. M., Mourgues, R., Galland, O., and Bureau, D. (2012). Fracture mode analysis and related surface deformation during dyke intrusion: Results from 2D experimental modelling. Earth Planet. Sci. Lett. , 359-360, 93-105. https://doi.org/10.1016/j.epsl.2012.10.008

Arlegui, L., and Simón, J. L. (2001). Geometry and distribution of regional joint sets in a non-homogeneous stress field: case study in the Ebro basin (Spain). J. Struct. Geol., 23(2-3), 297-313. https://doi.org/10.1016/S01918141(00)00097-3

Bai, T. X., and Pollard, D. D. (2000). Fracture spacing in layered rocks: a new explanation based on the stress transition. J. Struct. Geol., 22(1), 43-57. https://doi.org/10.1016/S0191-8141(99)00137-6

Bai, T. X., Maerten, L., Gross, M. R., and Aydin, A. (2002). Orthogonal cross joints: do they imply a regional stress rotation. J. Struct. Geol., 24(1), 77-88. https://doi.org/10.1016/S0191-8141(01)00050-5

Becker, A., and Gross, M. R. (1996). Mechanism for joint saturation in mechanically layered rocks: An example from southern Israel. Tectonophysics, 257(2-4), 223-237. https://doi.org/10.1016/00401951(95)00142-5

Brereton, R., Muller, B., Hancock, P., Harper, T., Bott, M. H. P., Sanderson, D., and Kusznir, N. (1991). European stress: Contributions from borehole breakouts [and Discussion]. Philos. Trans. :Phys. Sci. Eng., 337(1645), 165-179.

Caristan, Y. (1982). The transition from high temperature creep to fracture in 
Maryland diabase. J. Geophys. Res. :Solid Earth, 87(B8), 6781-6790. https://doi.org/10.1029/JB087iB08p06781

Carvalho, J. M. F. (2018). Jointing patterns and tectonic evolution of the Maciço Calcário Estremenho, Lusitanian Basin, Portugal. J. Struct. Geol., 110, 155-171. https://doi.org/10.1016/j.jsg.2018.03.004

Clerke, E. A. (1989). Borehole televiewer mudcake monitor. J. Acoust. Soc. Am., 85(4), 1807. https://doi.org/10.1121/1.397898

Cui, S. X., and Wang, H. L. (2011). Analytical study on results of acoustic downhole television in SICOMINES Cu-Co mining area of Congo. Site Invest. Sci. Technol. (in Chinese), (2), 51-53. https://doi.org/10.3969/j.issn.10013946.2011.02.013

Dai, Y. L., Wan, Y. G., Liang, Y. D., Zhang, W. J., and Hui, Y. (2020). Present tectonic stress field in Liaoning area based on earthquake focal mechanisms. Earthquake, 40(3), 112-130. https://doi.org/10.12196/j.issn.1000-3274.2020.03.009

Engelder, T., and Geiser, P. (1980). On the use of regional joint sets as trajectories of paleostress fields during the development of the Appalachian Plateau, New York. J. Geophys. Res. :Solid Earth, 85(B11), 6319-6341. https://doi.org/10.1029/JB085IB11P06319

Eyal, Y., Gross, M. R., Engelder, T., and Becker, A. (2001). Joint development during fluctuation of the regional stress field in southern Israel. J. Struct. Geol., 23(2-3), 279-296. https://doi.org/10.1016/S0191-8141(00)00096-1

Fang, H. H., Sang, S. X., Wang, J. L., Liu, S. Q., and Ju, W. (2017). Simulation of paleotectonic stress fields and distribution prediction of tectonic fractures at the Hudi Coal Mine, Qinshui Basin. Acta Geol. Sin., 91(6), 2007-2023. https://doi.org/10.1111/1755-6724.13447

Fang, L. P. (2015). The application of Acoustic Television in KOLWEZI of Democratic Republic of Congo. Ground Water, 37(2), 112-114. https://doi.org/10.3969/j.issn.1004-1184.2015.02.043

Faure, M., Lin, W., and Chen, Y. (2012). Is the Jurassic (Yanshanian) intraplate tectonics of North China due to westward indentation of the North China block. Terra Nova, 24(6), 456-466. https://doi.org/10.1111/ter.12002

Gao, J. W., Lin, Y., Zhang, C. H., Ding, Z. Y., Hou, L. Y., and Huang, Y. Z. (2019). Late Mesozoic Paleotectonic stress fields inferred from fault-slip data in central and western Yanshan Orogenic Belt: Implications for destructive geodynamics of North China Craton. Geoscience, 33(5), 919-936. https://doi.org/10.19657/j.geoscience.1000-8527.2019.05.01

Hancock, P. L., and Engelder, T. (1989). Neotectonic joints. GSA Bull., 101(10), 1197-1208. https://doi.org/10.1130/0016-7606(1989)101<1197:NJ>2.3. $\mathrm{CO} ; 2$

He, J., Wu, K., Zhang, J. T., and Peng, J. S. (2018). Cenozoic strike-slip fault system and its generating mechanism for Liaodong bay depression. Petrol. Geol. Oilfield Dev. Daqing (in Chinese), 37(2), 40-47. https://doi.org/10.19597/J.ISSN.1000-3754.201708076

Hou, Q. L., Liu, Q., Zhang, H. Y., Zhang, X. H., and Li, J. (2012). The Mesozoic tectonic dynamics and chronology in the eastern North China block. J. Geol. Res., 2012, 291467. https://doi.org/10.1155/2012/291467

Hu, X. P., Zang, A., Heidbach, O., Cui, X. F., Xie, F. R., and Chen, J. W. (2017). Crustal stress pattern in China and its adjacent areas. J. Asian Earth Sci., 149, 20-28. https://doi.org/10.1016/j.jseaes.2017.07.005

Hu, Z. W., Wang, D. Y., Niu, C. M., Yang, H. F., Xu, C. Q., Liu, Y. B., Ren, J., and Kang, L. (2019a). Characteristics of fault system and evaluation of hydrocarbon generation potential in western Liaoxi-Qinnan area, China. J. Chengdu Univ. Technol. (Sci. Technol. Ed. ), 46(5), 618-627. https://doi.org/10.3969/j.issn.1671-9727.2019.05.12

Hu, Z. W., Xu, C. G., Wang, D. Y., Ren, J., Liu, Y. B., Xiao, S. G., and Zhou, X. (2019b). Superimposed characteristics and genetic mechanism of strike-slip faults in the Bohai Sea, China. Petrol. Exp. Dev., 46(2), 254-267. https://doi.org/10.11698/PED.2019.02.06

Jiang, L., Qiu, Z., Wang, Q. C., Guo, Y. S., Wu, C. F., Wu, Z. J., and Xue, Z. H. (2016). Joint development and tectonic stress field evolution in the southeastern Mesozoic Ordos Basin, west part of North China. J. Asian Earth Sci., 127, 47-62. https://doi.org/10.1016/j.jseaes.2016.06.017

Jiang, S. E., Zhang, G. R., Pan, Y. Q., Lu, H. F., Wang, H. P., and Cheng, P. Q. (2010). Mesozoic intrusive rocks in western Liaoning: Basic characteristics and their relations to the tectonic movement. Geol. Resour., 19(1), 22-31. https://doi.org/10.3969/j.issn.1671-1947.2010.01.004

Juhlin, C., and Stephens, M. B. (2006). Gently dipping fracture zones in Paleoproterozoic metagranite, Sweden: Evidence from reflection seismic and cored borehole data and implications for the disposal of nuclear waste. J. Geophys. Res. :Solid Earth, 111 (B9), B09302. https://doi.org/10.1029/2005JB003887

Li, W., Ping, M. M., Zhou, D. H., Wu, K., Zhang, J., Fang, L., and Chen, X. P. (2018). Estimation of the Cenozoic strike-slip displacement for major faults in the Liaodong bay depression and its geological significance. Geotecton. Metall., 42(3), 445-454. https://doi.org/10.16539/j.ddgzyckx.2018.03.003

Li, W., Qi, J. Q., Zhou, D. H., Wu, K., Chen, X. P., and Guo, R. P. (2019). Formation and evolution of Liaoxi dome, Liaodong bay depression. Geotecton. Metall., 43(5), 911-923. https://doi.org/10.16539/j.ddgzyckx.2019.05.003

Li, Z., Li, Y., Zheng, J. P., and Han, D. (2007). Late Mesozoic tectonic transition of the eastern North China Craton: evidence from basin-fill records. Geol. Soc. Lond. Spe. Publ., 280(1), 239-265. https://doi.org/10.1144/SP280.12

Lin, Y., Zhang, C. H., Li, C. M., and Shi, X. L. (2015). Paleotectonic stress field and its evolution in central part of the Intraplate Yanshan Orogenic belt during Middle Jurassic and Early Cretaceous: Constrains of stress inversion of fault slip vectors. Geotecton. Metall., 39(2), 187-207. https://doi.org/10.3969/j.issn.1001-1552.2015.02.001

Liu, J. L., Davis, G. A., Ji, M., Guan, H. M., and Bai, X. D. (2008). Crustal detachment and destruction of the keel of North China Craton: Constraints from Late Mesozoic extensional structures. Earth Sci. Front., 15(3), 72-81. https://doi.org/10.1016/S1872-5791(08)60063-9

Liu, J. Y, Li, Q., Zhu, J. C., Wang, Y., and Xie, H. (2018). Geological evolution of the Liaoning area. Reg. Govern. (11), 274,276.

Liu, J. Z., Liu, X. S., Zhang, F. Q., Li, S. X., Li, G. L., and Ouyang, Z. Y. (2000). Characteristics and genesis of granitic complex in Fuxin-Jinzhou area, Liaoning province. Geol. Geochem., 28(4), 65-74. https://doi.org/10.3969/j.issn.1672-9250.2000.04.012

Liu, S. F., Su, S., and Zhang, G. W. (2013). Early Mesozoic basin development in North China: indications of cratonic deformation. J. Asian Earth Sci., 62, 221-236. https://doi.org/10.1016/j.jseaes.2012.09.011

Liu, S. F., Gurnis, M., Ma, P. F., and Zhang, B. (2017). Reconstruction of northeast Asian deformation integrated with western Pacific plate subduction since 200 Ma. Earth-Sci. Rev., 175, 114-142. https://doi.org/10.1016/j.earscirev.2017.10.012

Liu, S. F., Zhang, A. D., Lin, C. F., Zhang, B., Yuan, H. T., Huang, D. Y., Steel, R. J., and Horton, B. K. (2021). Thrust duplexing and transpression in the Yanshan Mountains: Implications for early Mesozoic orogenesis and decratonization of the North China Craton. Basin Res., 33(4), 2303-2327. https://doi.org/10.1111/BRE.12558

Ma, Y. (2004). Meso-Cenozoic Basin-Range Structures and Stress Field Evolution of the Eastern Yanshan-Lower Liaohe Basin (in Chinese). Beijing: Geological Publishing House.

MacLeod, C. J. , Parson, L. M. , and Sager, W. W. (1994). Reorientation of cores using the formation microscanner and borehole televiewer: application to structural and paleomagnetic studies with the Ocean Drilling Program. Proceedings of the Ocean Drilling Program, Scientific Results, 135, 301-311. https://doi.org/10.2973/odp.proc.sr.135.160.1994

Morin, R. H., Newmark, R. L., Barton, C. A., and Anderson, R. N. (1990). State of lithospheric stress and borehole stability at Deep Sea Drilling Project Site 504B, eastern equatorial Pacific. J. Geophys. Res. :Solid Earth, 95(B6), 9293-9303. https://doi.org/10.1029/JB095iB06p09293

Nie, X., Zou, C. C., Pan, L., Huang, Z. H., and Liu, D. M. (2013). Fracture analysis and determination of in-situ stress direction from resistivity and acoustic image logs and core data in the Wenchuan Earthquake Fault Scientific Drilling Borehole-2 (50-1370m). Tectonophysics, 593, 161-171. https://doi.org/10.1016/j.tecto.2013.03.005

Plumb, R. A., and Hickman, S. H. (1985). Stress-induced borehole elongation: A comparison between the four-arm dipmeter and the borehole televiewer in the Auburn Geothermal Well. J. Geophys. Res. :Solid Earth, 90(B7), 5513-5521. https://doi.org/10.1029/JB090iB07p05513

Pollard, D. D., and Aydin, A. (1988). Progress in understanding jointing over the past century. GSA Bull., 100(8), 1181-1204. https://doi.org/10.1130/0016- 
7606(1988) 100<1181:PIUJOT>2.3.CO;2

Price, N. J., and Cosgrove, J. W. (1990). Analysis of Geological Structures. Cambridge: Cambridge University Press.

Seeburger, D. A., and Zoback, M. D. (1982). The distribution of natural fractures and joints at depth in crystalline rock. J. Geophys. Res. :Solid Earth, 87(B7), 5517-5534. https://doi.org/10.1029/JB087iB07p05517

Shalaby, A. (2017). Fracture patterns of the drainage basin of Wadi Dahab in relation to tectonic-landscape evolution of the Gulf of Aqaba-Dead Sea transform fault. J. Asian Earth Sci., 148, 192-209. https://doi.org/10.1016/j.jseaes.2017.08.035

Shao, J. A., Mu, B. L., and Zhang, L. Q. (2000). Deep geological process and its shallow response during Mesozoic transfer of tectonic frameworks in eastern North China. Geol. Rev., 46(1), 32-40. https://doi.org/10.3321/j.issn:0371-5736.2000.01.005

Shao, J. A., Lu, F. X., Zhang, L. Q., and Shi, G. H. (2006). Temporal and spatial evidences for Early Cretaceous disturbance of the lithosphere beneath North China. Acta Petrol. Sin., 22(2), 277-284. https://doi.org/10.3969/j.issn.1000-0569.2006.02.002

Shi, Y. Y., Shang, Y. J., Sun, Y. C., and Wang, C. H. (2010). Applications of acoustic borehole televiewer in geotechnical investigation. Geotech. Invest. Surv. (in Chinese), 38(8), 82-87, 92.

Stone, D., Kamineni, D. C., Brown, A., and Everitt, R. (1989). A comparison of fracture styles in two granite bodies of the Superior province. Can. J. Earth Sci., 26(2), 387-403. https://doi.org/10.1139/e89-036

Tang, Q. S., and Chen, L. (2008). Structure of the crust and uppermost mantle of the Yanshan Belt and adjacent regions at the northeastern boundary of the North China Craton from Rayleigh wave dispersion analysis. Tectonophysics, 455(1-4), 43-52. https://doi.org/10.1016/j.tecto.2008.04.021

Wang, G. H., Zhang, C. H., Wang, G. S., and Wu, Z. W. (2001). Tectonic framework of western Liaoning province and its evolution during Mesozoic. Geoscience (in Chinese), 15(1), 1-7.

Wang, Y. (1996). Orogenic Process of the Inner Mongolia-Yanshanian Orogenic Bet from Later Paleozoic to Mesozoic, Eastern China (in Chinese). Beijing: Geological Publishing House.

Wong, W. H. (1927). Crustal movements and igneous activities in eastern China since Mesozoic time. Bull. Geol. Soc. China, 6(1), 9-37. https://doi.org/10.1111/j.1755-6724.1927.mp6001002.x

Wu, F. Y., Yang, J. H., Zhang, Y. B., and Liu, X. M. (2006). Emplacement ages of the Mesozoic granites in southeastern part of the Western Liaoning province. Acta Petrol. Sin., 22(2), 315-325. https://doi.org/10.3969/j.issn.1000-0569.2006.02.006

Xu, X. C., Zheng, C. Q., and Cui, F. H. (2017). Geochronology and Petrogenesis of Mesozoic Granitoids in the geological corridor of western Liaoning province, China. Acta Geol. Sin., 91(S1), 46-48. https://doi.org/10.1111/17556724.13176

Xu, Y. G., Li, H. Y., Pang, C. J., and He, B. (2009). On the timing and duration of the destruction of the North China Craton. Chin. Sci. Bull., 54(19), 3379-3396. https://doi.org/10.1007/s11434-009-0346-5

Yang, W. (2007). Geochronology and geochemistry of the Mesozoic volcanic rocks in Western Liaoning: Constraints on mechanism for the lithospheric thinning in the North China Craton (in Chinese). Hefei: University of Science and Technology of China.

Yang, W., and Li, S. G. (2008). Geochronology and geochemistry of the Mesozoic volcanic rocks in Western Liaoning: Implications for lithospheric thinning of the North China Craton. Lithos, 102(1-2), 88-117. https://doi.org/10.1016/j.lithos.2007.09.018

Yang, Z. , Chen, S. , and Dong, W. (2017). Regional Geology in Liaoning Province (in Chinese). Beijing: Geological Publishing House.

Zhai, M. G., and Fan, Q. C. (2002). Mesozoic replacement of bottom crust in North China Craton: anorogenic mantle-crust interaction. Acta Petrol. Sin., 18(1), 1-8. https://doi.org/10.3969/j.issn.1000-0569.2002.01.001

Zhai, M. G., Meng, Q. R., Liu, J. M., Hou, Q. L., Hu, S. B., Li, Z., Zhang, H. F., Liu, W., Shao, J. A., and Zhu, R. X. (2004). Geological features of Mesozoic tectonic regime inversion in Eastern North China and implication for geodynamics. Earth Sci. Front., 11(3), 285-297. https://doi.org/10.3321/j.issn:10052321.2004.03.027

Zhai, M. G. (2019). Tectonic evolution of the North China Craton. J. Geomech., 25(5), 722-745. https://doi.org/10.12090/j.issn.1006-6616.2019.25.05.063

Zhang, C. H., Song, H. L., Wang, G. H., Yan, D. P., and Sun, W. H. (2001). Mesozoic dextral strike-slip structural system in middle segment of Intraplate Yanshan Orogenic Belt, Northern China. Earth Sci. -J. China Univ. Geosci., 26(5), 464-472. https://doi.org/10.3321/j.issn:1000-2383.2001.05.004

Zhang, J., Wu, Z. P., Li, W., Xiao, Y., and Qi, J. Q. (2017). Cenozoic tectonic characteristics and evolution of Liaodong bay depression. Mar. Geol. Front., 33(11), 9-17. https://doi.org/10.16028/j.1009-2722.2017.11002

Zhang, Z. J., Chen, Q. F., Bai, Z. M., Chen, Y., and Badal, J. (2011). Crustal structure and extensional deformation of thinned lithosphere in Northern China. Tectonophysics, 508(1-4), 62-72.

https://doi.org/10.1016/j.tecto.2010.06.021

Zhao, G. C., Sun, M., Wilde, S. A., and Li, S. Z. (2005). Late Archean to Paleoproterozoic evolution of the North China Craton: key issues revisited. Precam. Res., 136(2), 177-202. https://doi.org/10.1016/j.precamres.2004.10.002

Zhao, Y. (1990). The Mesozoic orogenies and tectonic evolution of the Yanshan area. Geol. Rev., 36(1), 1-13. https://doi.org/10.3321/j.issn:03715736.1990 .01 .001

Zhao, Y., Yang, Z., and Ma, X. (1994). Major transition of tectonics of eastern Asia. Scientia Geologica Sinica, 29(2), 105-119.

Zhao, Y., Cui, S. Q., Guo, T., and Xu, G. (2002). Evolution of a Jurassic basin of the Western Hills, Beijing, North China and its tectonic implications. Geol. Bull. China, 21(4), 211-217. https://doi.org/10.3969/j.issn.1671-2552.2002.04.006

Zheng, T. Y., Chen, L., Zhao, L., and Zhu, R. X. (2007). Crustal structure across the Yanshan belt at the northern margin of the North China Craton. Phys. Earth Planet. Inter., 161(1-2), 36-49. https://doi.org/10.1016/j.pepi.2007.01.004

Zheng, Y. D., Davis, G. A., Wang, C., Darby, B. J., and Zhang, C. H. (2000). Major Mesozoic tectonic events in the Yanshan belt and the plate tectonic setting. Acta Geol. Sin., 74(4), 289-302. https://doi.org/10.3321/j.issn:00015717.2000.04.001

Zhu, R. X., Chen, L., Wu, F. Y., and Liu, J. L. (2011). Timing, scale and mechanism of the destruction of the North China Craton. Sci. China Earth Sci., 54(6), 789-797. https://doi.org/10.1007/s11430-011-4203-4

Zhu, R. X., Xu, Y. G., Zhu, G., Zhang, H. F., Xia, Q. K., and Zheng, T. Y. (2012). Destruction of the North China Craton. Sci. China Earth Sci., 55(10), 1565-1587. https://doi.org/10.1007/s11430-012-4516-y

Zhu, R. X., Fan, H. R., Li, J. W., Meng, Q. R., Li, S. R., and Zeng, Q. D. (2015). Decratonic gold deposits. Sci. China Earth Sci., 58(9), 1523-1537. https://doi.org/10.1007/s11430-015-5139-x

Zoback, M. L. (1992). First- and second-order patterns of stress in the lithosphere: The world stress map project. J. Geophys. Res. :Solid Earth, 97(B8), 11703-11728. https://doi.org/10.1029/92JB00132 